\title{
PENERAPAN CORPORATE SOCIAL RESPONSIBILITY (CSR) DALAMPANDANGAN ISLAM
}

\author{
Budi Gautama Siregar \\ Fakultas ekonomi dan Bisnis Islam IAIN Padangsidimpuan \\ J1. H.T. Rizal Nurdin Km. 4,5 Sihitang, Padangsidimpuan 22733 \\ e-mail: gautamasiregar@yahoo.com
}

\begin{abstract}
Corporate Social Responsibility (CSR) is basically the moral responsibility of companies and enterprises toward societies. The responsibility itself can be initiated by the company itself, employees, other companies, social environments, and even the State where the business is established. The concept of CSR can be seen from two different perspectives. First, it concerns with the company's goal is for profit. Therefore, CSR is believed to be parts of business. Second, it deals with the purpose of a company is for profit while ensuring people's welfare and environmental sustainability become prior concerns. Islam strongly supports CSR since it cannot be denied that the businesses create a lot of unexpected social problems. Consequenty, it is the companies and enterprises' responsibility to fix those problems. This is reasonable since they need to explore a variety of natural resources for business sustainability, therefore, they should be responsible for the people and environment in return.
\end{abstract}

Kata kunci: implementasi, tanggung jawab sosial perusahaan, pandangan Islam

PENDAHULUAN

K egiatan yang dilakukan seringkali menimbulkan berbagai persoalan diantaranya sengketa lahan, kerusakan lingkungan, dan kesejahteraan bagi masyarakat yang ada di sekitar perusahaan beroperasi (Erni Dwijayanti: 2013: t.h.). Persoalan-persoalan yang ditimbulkan oleh aktivitas perusahaan tersebut perlu dilakukan penanganan agar dapat diminimalisir atau bahkan dihilangkan. Di samping itu juga kegiatan yang dilakukan oleh perusahaan tersebut memiliki dampak yang positif dalam sisi ekonomi maupun sosial. Dari pemahaman inilah yang menjadi dasar adanya laporan pertanggungjawaban sosial perusahaan atau corporate sosial responsibility (Widagya dan Triani, 2014: t.h.).

Perkembangan pelaksanaan pertanggungjawaban sosial perusahaan (CSR) sejalan dengan Undang-Undang yang berlaku di Indonesia yaitu UU No. 47 Tahun 2012 tentang Perseroan Terbatas pasal 3 Ayat 1 mengenai Tanggung Jawab Sosial dan Lingkungan, yang menyatakan bahwa: "Tanggung jawab sosial dan lingkungan menjadi kewajiban bagi Perseroan yang menjalankan kegiatan usahanya di bidang dan/atau berkaitan dengan sumber daya alam berdasarkan Undang-Undang.". Dengan adanya 
peraturan tersebut, maka semakin mendukung perkembangan pelaporan CSR di Indonesia. Dalam pelaksanaan tanggung jawab sosial tersebut perusahaan harus bisa memberikan informasi mengenai kegiatan atau aktivitas yang berkaitan dengan sosial masyarakat dan lingkungan sebagai bentuk tanggung jawab perusahaan, serta memberikan pelaporan dan pengungkapan atas aktivitas tersebut. Tetapi dalam hal pengungkapan, perusahaan masih belum diwajibkan, melainkan masih bersifat pengungkapan sukarela (voluntary) dan belum ada peraturan khusus mengenai luas pengungkapan tanggung jawab sosial dan lingkungan perusahaan ( Pradipta, D.H. dan Purwaningsih, Simposium Nasional Akuntansi XV. Banjarmasin, 2012).

Tanggung jawab sosial merujuk pada kewajiban-kewajiban sebuah organisasi untuk melindungi dan memberi kontribusi kepada masyarakat di mana ia berada. Sebuah organisasi mengemban tanggung jawab sosial dalam tiga domain yaitu pada pelaku organisasi, pada lingkungan alam, dan pada kesejahteraan sosial secara umum. Tanggung jawab sosial sangatlah harus dijalankan, karena hal itu akan berdampak pada image organisasi atau perusahaan di mata lingkungannya.

Dalam Alquran, Allah berfirman :

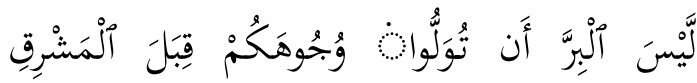

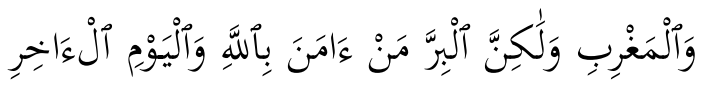

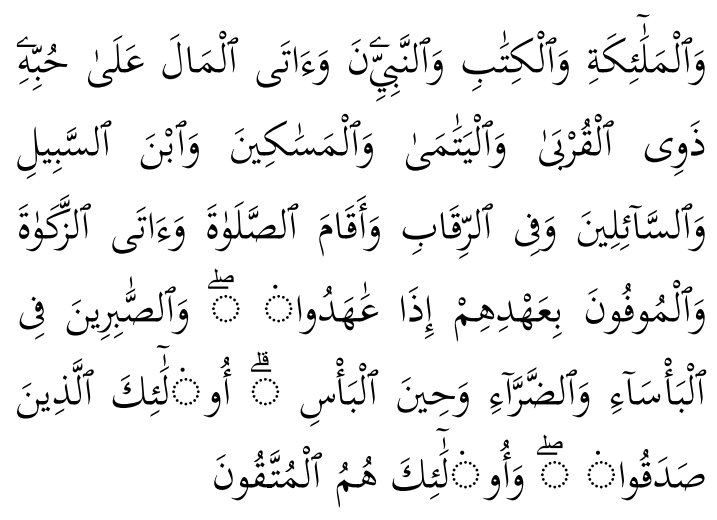

"Bukanlah menghadapkan wajahmu ke arah timur dan barat itu suatu kebajikan, akan tetapi Sesungguhnya kebajikan itu ialah beriman kepada Allah, hari Kemudian, malaikatmalaikat, kitab-kitab, nabi-nabi dan memberikan harta yang dicintainya kepada kerabatnya, anak-anak yatim, orang-orang miskin, musafir (yang memerlukan pertolongan) dan orangorang yang meminta-minta; dan (memerdekakan) hamba sahaya, mendirikan shalat, dan menunaikan zakat; dan orang-orang yang menepati janjinya apabila ia berjanji, dan orang-orang yang sabar dalam kesempitan, penderitaan dan dalam peperangan. mereka Itulah orangorang yang benar (imannya); dan mereka Itulah orang-orang yang bertakwa". (QS. al-Baqarah [2]:177)

Dari ayat di atas dapat diambil kesimpulan bahwa Islam adalah agama yang mengedepankan pentingnya nilai-nilai sosial di masyarakat ketimbang hanya sekedar menghadapkan wajah kita ke barat dan ke timur dalam shalat. Tanpa mengesampingkan akan pentingnya shalat dalam Islam, $\mathrm{Al}$ Quran mengintegrasikan makna dan tujuan shalat dengan nilai-nilai sosial. Di samping memberikan nilai keimanan berupa iman kepada Allah 
SWT, Kitab-Nya, dan Hari Kiamat, alquran menegaskan bahwa keimanan tersebut tidak sempurna jika tidak disertai dengan amalanamalan sosial berupa kepedulian dan pelayanan kepada kerabat, anak yatim, orang miskin, dan musafir serta menjamin kesejahteraan mereka yang membutuhkan.

Dalam konteks ini, maka CSR dalam perspektif Islam adalah praktik bisnis yang memiliki tanggung jawab etis secara islami. Perusahaan memasukan normanorma agama Islam yang ditandai dengan adanya komitmen ketulusan dalam menjaga kontrak sosial di dalam operasinya. Dengan demikian, praktik bisnis dalam kerangka CSR Islami mencakup serangkaian kegiatan bisnis dalam bentuknya. Meskipun tidak dibatasi jumlah kepemilikan barang, jasa serta profitnya, namun cara-cara untuk memperoleh dan pendayagunaannya dibatasi oleh aturan halal dan haram oleh syariah. CSR dalam perspektif Islam menurut AAOIFI yaitu segala kegiatan yang dilakukan institusi finansial Islam untuk memenuhi kepentingan religius, ekonomi, hukum, etika, dan discretionary responsibilities sebagai lembaga finansial intermediari baik bagi individu maupun institusi.

\section{SEJARAH DAN DEFINISI CORPORATE SOCIAL RESPONSIBILITY}

\section{Sejarah}

Gerakan-gerakan dari corporate social reponsibility kontemporer telah berkembang selama dua puluh tahun terakhir ini, hal ini disebabkan karena adanya desakan organisasiorganisasi masyarakat beserta jaringannya di tingkat internasional. Berikut ini perkembangan corporate social responsibility setelah Howard R. Bowen (1950-an), yaitu :

\section{Tahun 1960-an}

Pada tahun 1960-an banyak usaha dilakukan untuk memberikan formalisasi definisi CSR. Salah satu akademisi CSR yang terkenal pada masa itu adalah Keith Davis. Davis dikenal karena berhasil memberikan pandangan yang mendalam atas hubungan antara CSR dengan kekuatan bisnis. Davis mengutarakan "Iron Law of Responsibility" yang menyatakan bahwa tanggung jawab sosial pengusaha sama dengan kedudukan sosial yang mereka miliki. Tahun 1962, Rachel Carlson menulis buku yang berjudul Silent Spring yang memberikan pengaruh besar pada aktivitas pelestarian alam. Tahun 1963 Joseph W. McGuire memperkenalkan istilah Corporate Citizenship, yang menyatakan bahwa korporasi harus memperhatikan masalah politik, kesejahteraan masyarakat, pendidikan, "kebahagiaan" karyawan, dan seluruh permasalahan sosial kemasyarakatan lainnya. Oleh karena itu, korporasi harus bertindak "baik" sebagai mana warga negara (citizen) yang baik (Siswoyo, B.B. et. al., 2009: t.h.).

\section{Tahun 1970-an}

S. Prakash Sethi memberikan penjelasan atas perilaku korporasi yang dikenal dengan social obligation, 
social responsibility, dan social responsiveness. Social obligation adalah perilaku korporasi yang didorong oleh kepentingan pasar dan pertimbangan-pertimbangan

hukum. Social responsibility merupakan perilaku korporasi yang tidak hanya menekankan pada aspek ekonomi dan hukum saja, tetapi menyelaraskan social obligation dengan norma, nilai, dan harapan kinerja yang dimiliki oleh lingkungan sosial.

\section{Tahun 1980-an}

Pakar teori manajemen Peter F. Drucker baru mulai membahas secara serius bidang CSR pada tahun 1984. Ia memberikan ide baru agar korporasi dapat mengelola aktivitas CSR yang dilakukannya dengan sedemikian rupa sehingga tetap akan menjadi peluang bisnis yang menguntungkan. Tahun 1987, Persatuan Bangsa-Bangsa melalui World Commission on Environment and Development (WECD) menerbitkan laporan yang berjudul Our Common Future. Laporan ini menjadi dasar kerjasama multilateral dalam rangka melakukan berkelanjutan pembangunan development).

\section{Tahun 1990-an ke atas}

Keprihatinan utama yang disuarakan pada periode ini adalah mengenai perilaku korporasi. Demi maksimalisasi labanya, lazim mempraktikkan cara-cara yang tidak etis, dan dalam banyak kasus bahkan dapat dikategorikan sebagai kejahatan korporasi. Atas prakarsa banyak pihak, dilakukan KTT Bumi (Earth Summit) di Rio de Janeiro,
Brazilia tahun 1992. KTT dihadiri oleh 172 negara dengan tema utama Lingkungan dan Pembangunan Berkelanjutan. Earth Summit ini menghasilkan "Deklarasi Rio" yang menegaskan bahwa konsep pembangunan berkelanjutan (sustainability development) tidak hanya menjadi tanggung jawab negara, tetapi utamanya juga perusahaan yang kekuasaannya semakin menggurita. Hasil akhir dari pertemuan tersebut secara garis besar menekankan pentingnya ecoefficiency dijadikan sebagai prinsip utama berbisnis dan menjalankan pemerintahan. Hasil KTT Bumi ini semakin dipertegas oleh hasil riset James Colins dan Jerry Porras, yang menyatakan bahwa perusahaanperusahaan yang bertahan lama adalah perusahaan yang bukan hanya mengejar profit semata (Kalangit, KM, 2009: t.h.). Selanjutnya, pertemuan di Johannesburg pada tahun 2002 yang dihadiri oleh para pemimpin dunia memunculkan konsep social responsibility, yang mengikuti dua konsep yang telah muncul sebelumnya yaitu economic dan environmental sustainability. Dalam tahun yang sama, di Amerika dikeluarkan Sarbanas-Oxley 2002 yang di antaranya mengatur kewajiban direktur dalam membuat laporan keuangan perusahaan sebagai upaya untuk meningkatkan tanggung jawab sosial perusahaan. Demikian juga di Inggris, dalam Companies Act versi 2007 yang mengatur peningkatan kewajiban direktur untuk melaporkan financial key performance indicator dan laporan 
yang berisi informasi terkait dengan lingkungan perusahaan dan para pekerjanya. Pertengahan tahun 2007, UN Global Compact yang dibuka oleh Sekretaris Jenderal PBB, meminta perusahaan untuk menunjukkan tanggung jawab dan perilaku bisnis yang sehat. Selain itu, International Organization of Standardization (ISO) sejak tahun 2004 telah menyusun panduan standardisasi untuk CSR (Guidance Standard on Social Responsibility) yang kemudian dikenal sebagai ISO 26000 dan diberlakukan tahun 2009 (Kalangit, KM, 2009: t.h.).

Di Indonesia tanggung jawab sosial/corporate social responsibility merupakan etika bisnis yang tidak tertulis sebelum dilahirkan UndangUndang Penanaman Modal dan Undang-Undang Perseroan Terbatas. Namun setelah diundangkannya Undang-Undang No.40 Tahun 2007 dan Undang-Undang No.25 Tahun 2007 maka etika ini telah menjadi normatif. Dalam Undang-Undang Nomor 25 tahun 2007 tentang Penanaman Modal, pasal 15 menyebutkan bahwa setiap penanam modal berkewajiban :

1. Menerapkan prinsip tata kelola perusahaan yang baik.

2. Melaksanakan tanggung jawab sosial perusahaan.

3. Membuat laporan tentang kegiatan penanaman modal dan menyampaikannya kepada Badan Koordinasi Penanaman Modal.

4. Mematuhi semua ketentuan peraturan perundang-undangan.

Pasal 15 (b) lebih lanjut menerangkan bahwa "tanggung jawab sosial perusahaan" adalah tanggung jawab yang melekat pada setiap perusahaan penanaman modal untuk tetap menciptakan hubungan yang serasi, seimbang, dan sesuai dengan lingkungan, nilai, norma, dan budaya masyarakat setempat. Undang-Undang Nomor 40 tahun 2007 tentang Perseroan Terbatas pasal 74 yang menentukan bahwa:

1. Perseroan yang menjalankan kegiatan usahanya di bidang dan/ atau berkaitan dengan sumber daya alam wajib melaksanakan Tanggung Jawab Sosial dan Lingkungan

2. Tanggung Jawab Sosial dan Lingkungan merupakan kewajiban Perseroan yang dianggarkan dan diperhitungkan sebagai biaya Perseroan yang pelaksanaannya dilakukan dengan memperhatikan kepatutan dan kewajaran

3. Perseroan yang tidak melaksanakan kewajiban Tanggung Jawab Sosial dan Lingkungan akan dikenai sanksi sesuai dengan ketentuan peraturan perundang-undangan.

4. Ketentuan lebih lanjut mengenai Tanggung Jawab Sosial dan Lingkungan diatur dengan Peraturan Pemerintah.

Selanjutnya dalam Pasal 74 ayat (3) dijelaskan bahwa yang dimaksud "dikenai sanksi sesuai dengan ketentuan peraturan perundangundangan" adalah dikenai segala bentuk sanksi yang diatur dalam peraturan perundang-undangan yang terkait.

Dalam menjalankan tanggung jawab sosialnya, perusahaan 
memfokuskan perhatiannya kepada tiga hal yaitu keuntungan (profit), masyarakat (people), dan lingkungan (planet). Perusahaan harus memiliki tingkat profitabilitas yang memadai, sebab laba merupakan fondasi bagi perusahaan untuk dapat berkembang dan mempertahankan eksistensinya. Dengan perolehan laba yang memadai, perusahaan dapat membagi deviden kepada pemegang saham, memberi imbalan yang layak kepada karyawan, mengalokasikan sebagian laba yang diperoleh untuk pertumbuhan dan pengembangan usaha di masa depan, membayar pajak kepada pemerintah, dan memberikan banyak dampak yang diharapkan kepada masyarakat.

Dengan

memperhatikan

masyarakat, perusahaan dapat berkontribusi terhadap peningkatan kualitas hidup masyarakat. Perhatian terhadap masyarakat dapat dilakukan dengan cara perusahaan melakukan aktivitasaktivitas serta pembuatan kebijakankebijakan yang dapat meningkatkan kesejahteraan, kualitas hidup dan kompetensi masyarakat di berbagai bidang. Dengan memperhatikan lingkungan, perusahaan dapat ikut berpartisipasi dalam usaha pelestarian lingkungan demi terpeliharanya kualitas hidup umat manusia dalam jangka panjang. Keterlibatan perusahaan dalam pemeliharaan dan pelestarian lingkungan berarti perusahaan berpartisipasi dalam usaha mencegah terjadinya bencana serta meminimalkan dampak bencana yang diakibatkan oleh kerusakan lingkungan. Dengan menjalankan tanggungjawab sosial, perusahaan diharapkan tidak hanya mengejar laba jangka pendek, tetapi juga ikut berkontribusi terhadap peningkatan kualitas hidup masyarakat dan lingkungan (terutama lingkungan sekitar) dalam jangka panjang.

\section{Definisi}

Corporation atau korporasi, sebagaimana sudah dipakai dalam bahasa Indonesia, langsung dimengerti sebagai perusahaan, khususnya perusahaan besar tetapi pengertian dari perusahaan ini lebih luas, yaitu badan hukum "korporasi" berasal dari bahasa latin (corpus/ corpora: badan) dan sebetulnya berarti badan hukum (K. Bertens, t.th.: 289). Responsibility (tanggung jawab) yaitu terdiri dari dua suku kata yaitu response (tanggapan) dan ability (kemampuan), sehingga pada dasarnya tanggung jawab menunjukkan kemampuan yang dimiliki seseorang atau sebuah organisasi perusahaan untuk memberikan tanggapan terhadap berbagai hal yang dimintakan tanggapannya kepada orang atau perusahaan tersebut terhadap pihak lain (Ismail Sholihin, 2006: 109).

$$
\text { Tanggung jawab itu }
$$
diterjemahkan dengan kata "Responsibility: having the character of a free moral agent, capable of determining one's own act; capable of deterred by consideration of sanction or consequences"definisi ini memberikan pengertian yang menitik beratkan pada, harus ada kesanggupan untuk menetapkan sikap terhadap suatu 
perbuatan, harus ada kesanggupan memikul resiko dari suatu perbuatan (Burhanudin Salam, 2002: 28). Tanggung jawab merupakan suatu prinsip yang dinamis yang berhubungan dengan keseluruhan perilaku manusia dalam hubungannya dengan masyarakat maupun istitusi. Suatu tanggung jawab bahkan mempunyai kekuatan dinamis untuk mempertahankan kualitas keseimbangan dalam masyarakat, sehingga menjadikan kesinambuangan antara yang satu dengan yang lainnya.

Tanggung jawab sendiri memiliki tiga unsur yaitu:

1. Kesadaran (awareness). Berarti tahu atau mengetahui, mengenal, dengan kata lain, perusahaan baru dapat dimintai pertangung jawaban, bila yang bersangkutan sadar akan yang dilakukannya.

2. Kecintaan atau kesukaan (affiction). Berarti suka, menimbulkan rasa kepatuhan, kerelaan, dan kesediaan berkorban. Rasa cinta timbul atas dasar kesadaran, apabila tidak ada rasa kesadaran berarti rasa kecintaan tersebut tidak akan muncul. Jadi kesukaan atau kecintaan tumbuh atas dasar kesadaran, dan atas dasar kesadaran inilah muncul atau lahirlah rasa tanggung jawab.

3. Keberanian (bravery), berarti suatu rasa yang didorong oleh rasa keikhlasan, tidak ragu-ragu dan tidak takut dengan segala rintangan.

Tanggung jawab sosial merujuk pada kewajiban-kewajiban sebuah organisasi untuk melindungi dan memberikan kontribusi kepada masyarakat di mana ia berada, sebuah organisasi ia mengemban tanggung jawab sosial dalam tiga domain: pelaku organisasi, pada lingkungan alam, pada kesejahteraan sosial secara umum (Rafik Isa, 2004: 63). Corporate Social Responsibility (CSR) adalah komitmen perusahaan atau dunia bisnis untuk berkontribusi dalam pengembangan ekonomi yang berkelanjutan dengan memperhatikan tanggung jawab perusahaan dan menitikberatkan pada keseimbangan antara perhatian terhadap aspek ekonomi, sosial, dan lingkungan (Hendrik Budi, t.th.: 1). Dengan kata lain, hal ini merupakan pengambilan keputusan yang dikaitkan dengan nilai-nilai etika, memenuhi kaidah-kaidah dan keputusan hukum dan menghargai manusia, masyarakat, dan lingkungan.

Definisi dari Corporate Social Responsibility (CSR) adalah suatu tindakan atau konsep yang dilakukan oleh perusahaan (sesuai kemampuan perusahaan tersebut) sebagai bentuk dari tanggung jawab mereka terhadap sosial atau lingkungan sosialnya dimana perusahaan itu berada atau untuk berperilaku etis dan berkontribusi secara positif kepada karyawannya, komunitas dan lingkungan sekitarnya, serta masyarakat luas (Yusuf Wibisono,t.th.: 8). Pengertian Corporate Social Responsibility berdasarkan ISO 26000 Draft 4.1 (Maret 2008) adalah Responsibility of an organization for the impacts of its decisions and activities on society and the environment, through transparent 
and ethical behaviour that contributes to sustainable development, health and the welfare of society; takes into account the expectations of stakeholders; is in compliance with applicable law and consistent with international norms of behaviour; and is integrated throughout the organization and practiced in its relationships.(Tanggung jawab sebuah organisasi atau perusahaan atas dampak dari keputusan dan aktifitas organisasi atau perusahaan tersebut kepada masyarakat dan lingkungan, yang transparan dan perilaku yang etis memberikan konstribusi atau sumbangan atas pembangunan berkelanjutan, kesehatan, dan kesejahteraan mayarakat; memperhitungkan harapan para pemangku kepentingan; sudah sesuai dengan hukum yang berlaku, konsisten dengan norma-norma perilaku internasional dan terintegrasi di seluruh organisasi dan dipraktekkan dalam hubungan organisasi)

Definisi CSR oleh World Bank sebagai Lembaga keuangan global, memandang CSR : "the commitment of business to contribute to sustainable economic development working with employees and their representative the local community and society at large to improve quality of life, in ways that are both good for business and good for development." (yaitu komitmen bisnis untuk memberikan kontribusi untuk pembangunan ekonomi berkelanjutan bekerjasama dengan para pegawai dan melibatkan komunitas lokal serta masyarakat luas untuk meningkatkan kualitas hidup, yang mana cara- cara ini baik untuk bisnis dan pembangunan).
Corporate Social Responsibility
(CSR) Forum juga memberikan
defenisi, "CSR means open and
transparent business practices that are
based on ethical values and respect for
employees, communities and
environment." (Corporate Social Responsibility (CSR) berarti praktek bisnis yang terbuka dan transparan berdasarkan nilai-nilai etis dan penghargaan bagi para pegawai, komunitas dan lingkungan). Sementara sejumlah negara juga mempunyai defenisi tersendiri mengenai CSR (Nor Hadi, 2011: 47). Uni Eropa (EU Green Paper on CSR) mengemukakan bahwa "CSR is a concept whereby companies integrate social and environmental concerns in their business operations and in their interaction with their stakeholders on a voluntary basic." (Corporate Social Responsibility (CSR) adalah suatu konsep dimana perusahaan mengintegrasikan keprihatinan terhadap lingkungan dan sosial terhadap kegiatan bisnis dan interaksi mereka dengan stakeholder mereka berlandaskan dasar sukarela) (Yusuf Wibisono,t.th.: 9).

Menurut defenisi "The Jakarta Consulting Group", tanggung jawab sosial diarahkan baik ke dalam (internal) maupun keluar (eksternal) perusahaan. Tanggungjawab internal (Internal Responsibilities) diarahkan kepada pemegang saham dalam bentuk profitabilitas yang optimal dan pertumbuhan perusahaan, termasuk juga tanggung jawab yang diarahkan kepada karyawan terhadap kontribusi mereka kepada perusahaan berupa kompensasi yang 
adil dan peluang pengembangan karir.

Sedangkan tanggung jawab eksternal (External Responsibilities) berkaitan dengan peran perusahaan sebagai pembayar pajak dan penyedia lapangan kerja, meningkatkan kesejahteraan dan kompetensi masyarakat, serta memelihara lingkungan bagi kepentingan generasi mendatang. Secara umum Corporate Social Responsibility (CSR) merupakan peningkatan kualitas hidup mempunyai arti adanya kemampuan manusia sebagai individu anggota masyarakat untuk dapat menanggapi keadaan sosial yang ada, dan dapat menikmati, memanfaatkan serta memelihara lingkungan hidup atau dapat dikatakan sebagai proses penting dalam pengaturan biaya yang dikeluarkan dan keuntungan kegiatan bisnis dari stakeholders baik secara internal maupun secara eksternal.

Tanggung jawab sosial perusahaan adalah tanggung jawab moral perusahaan terhadap masyarakat, tanggung jawab disini bisa diarahkan mulai dari perusahaan itu sendiri, karyawan, perusahaan lain, lingkungan sosial, dan bahkan bisa tanggung jawab dengan Negara tempat usaha didirikan, tanggung jawab itu sendiri merupakan suatu prinsip dinamis yang berhubungan dengan masyarakat atau institusi. Berbicara mengenai Corporate Social Responsibility (CSR) yang harus dilaksanakan sebuah perusahaan maka kita akan melihat dua makna yang terkadung dalam tahapan penerapan Corporate Social Responsibility (CSR), yaitu tanggung jawab dalam makna responsibility atau tanggung jawab moral dan etis dan tanggung jawab dalam makna liability atau tanggung jawab yuridis atau hukum. Tanggung jawab dalam makna responsibility atau tanggung jawab moral dan etis yaitu lebih menekankan pada perbuatan yang harus atau wajib dilakukan secara sadar dan siap untuk menanggung segala resiko dan atau konsekwensi apapun dari perbuatan yang didasarkan atas moral tersebut. Dengan kata lain responsibility merupakan tanggung jawab dalam arti sempit yaitu tanggung jawab yang hanya disertai sanksi moral.

Tanggung jawab dalam makna liability atau tanggung jawab yuridis atau hukum, biasanya diwujudkan dengan bentuk tanggung jawab keperdataan. Yaitu dengan melaksanakan segala sesuatunya sesuai hukum yang berlaku, dan apabila terdapat permasalahan terkait dengan hukum maka diselesaikan secara hukum keperdataan. Tanggung jawab hukum ini mutlak dilakukan ketika ada ketidak sesuaian hukum dalam pelaksanaan kegiatan lembaga.

Dalam konsep CSR selain perusahaan bertanggung jawab secara ekonomi dalam bentuk profit pada pemegang sahamnya, perusahaan juga harus menjalankan bisnisnya sesuai hukum yang berlaku, menerapkan etika, moral, dan derma kepedulian (filantrofi) terhadap lingkungannya. 
Berdasarkan uraian diatas, dapat disimpulkan perbedaaan antara tanggung jawab dalam makna responsibility dan tanggung jawab dalam makna liability, pada dasarnya terletak pada sumber pengaturanya. Jika tanggung jawab belum ada pengaturannya secara eksplisit dalam suatu norma hukum, maka termasuk dalam makna responsibility dan sebaliknya jika tanggung jawab itu telah diatur didalam norma hukum, maka termasuk dalam makna liability(Isa Wahyudi dan Bursa Azheri, 2011: 2).

Implementasi konsep CSR membawa konsekuensi bahwa perusahaan juga harus memiliki tanggung jawab terhadap pihakpihak lain seperti karyawan, supplier, konsumen, pemerintah, kelompok masyarakat setempat dan yang lebih luas. Masih banyak pihak yang menyamakan CSR dengan pengembangan masyarakat atau community development (CD). CD merupakan usaha sistematis untuk meningkatkan kekuatan kelompokkelompok masyarakat kurang beruntung (spesifik) agar lebih dekat dengan kemandirian. Adapun CSR mempunyai cakupan yang lebih luas, yaitu terhadap seluruh stakeholders. Jadi, CD merupakan bagian dari CSR.

\section{KONSEP CORPORATE SOCIAL RESPONSIBILITY (CSR)}

Konsep Corporate Social Responsibility (CSR) secara etik, tidak dapat dilepaskan dari adanya konsep etika bisnis. Pemikiran yang mendasari CSR dalam hubungannya dengan Etika Bisnis adalah bahwa perusahaan tidak hanya mempunyai kewajiban-kewajiban ekonomis dan legal tetapi juga kewajibankewajiban terhadap pihak-pihak yang berkepentingan (stakeholders), karena perusahaan tidak bisa hidup, beroperasi dan memperoleh keuntungan tanpa bantuan pihak lain. CSR merupakan pengambilan keputusan perusahaan yang dikaitkan dengan nilai-nilai etika, dapat memenuhi kaidah-kaidah dan keputusan hukum dan menjunjung tinggi harkat manusia, masyarakat dan lingkungan. Tanggung jawab sosial perusahaan meliputi bidang sosial, ekonomi dan lingkungan.

$$
\text { Konsep Corporate Social }
$$

Responsibility (CSR) dapat dilihat dari dua sudut pandang yang berbeda konsep pertama menyatakan bahwa tujuan perusahaan adalah mencari profit semata, sehingga Corporate Social Responsibility (CSR) merupakan bagian bisnis. Sedangkan konsep kedua menyatakan bahwa tujuan perusahaan adalah mencari laba (profit), mensejahterakan orang (people) dan menjamin keberlanjutan lingkungan (planet), kedua konsep ini sangat berbeda. Konsep Corporate Social Responsibility (CSR) melibatkan tanggung jawab kemitraan antara pemerintah, lembaga sumberdaya komunitas, juga komunitas setempat (local). Kemitraan ini, tidaklah bersifat pasif dan statis, kemitraan ini merupakan tanggung jawab bersama secara sosial antara stakeholder. Konsep kedermawanan perusahaan atau (Corporate Philanthropy) dalam tanggung jawab 
sosial tidak lagi memadai, karena itu konsep itu tidak melibatkan tanggung jawab perusahaan secara sosial dengan stakeholder lainya.

Kegiatan program yang dilakukan perusahaan dalam konteks bertanggung jawab sosialnya dapat dikategorikan dalam tiga bentuk:

1. Public Relation (Hubungan Publik)

Usaha untuk menanam persepsi positif kepada komunitas tentang kegiatanyang dilakukan oleh perusahaan. Biasanya berbentuk kampanye yang tidak terkait sama sekali dengan produk yang dihasilkan oleh perusahaan tersebut.

2. Strategi Defensive (Pertahanan Kedudukan)

Pada public relation, pada dasarnya menjalin hubungan yang belum ada, sedangkan pada strategi defensive mengarah pada proses melawan kejadian yang pernah dialami, artinya anggapan komunitas terhadap perusahaan sudah ada sebelumnya dan anggapan ini biasanya bernada negative yang pada umumnya bicara tentang aktivitas dari perusahaan yang bersangkutan yang negative terhadap suatu hal, usaha Corporate Social Responsibility (CSR) yang dilakukan adalah untuk merubah anggapan yang berkembang sebelumnya dengan menggantinya dengan yang baru sebagai suatu anggapan baru yang bersifat posistif.

3. Keinginan Tulus Untuk Melakukan Kegiatan Yang Baik dan Benar-benar Berasal dari Visi Perusahaan itu

Melakukan program untuk kebutuhan komunitas atau komunitas sekitar perusahaan atau kegiatan perusahaan atau yang berbeda dari hasil perusahaan itu sendiri. Kegiatan perusahaan dalam konteks ini adalah sama sekali tidak mengambil suatu keuntungan secara materil tetapi berusaha menanamkan kesan baik terhadap komunitas yang berkaitan dengan perusahaan.

Suatu perusahaan merupakan bagian dari suatu system ekonomi yang lebih besar. Kelompok-kelompok atau individu-individu (stakeholder) lain dapat mempengaruhi bagaimana suatu perusahaan dikelola. Kelompok atau individuindividu tersebut adalah para pemilik perusahaan, tenaga kerja yang bekerja pada perusahaan, para pelanggan yang membeli barang atau jasa, para pemasok yang menjual bahan baku, mesin, dan peralatan pada perusahaan.Perusahaan juga harus taat atau patuh kepada hukum dan peraturan-peraturan pemerintah, menjadi perusahaan yang baik di masyarakat sekitarnya, dan mematuhi keputusan-keputusan dari asosiasi bisnis dimana perusahaan menjadi anggotanya. Apabila karyawan tidak membentuk serikat kerja, perusahaan harus mengakui serikat kerja yang ada dan melakukan negosiasi dengan serikat kerja tersebut.Seorang 
manajer dipekerjakan untuk menjalankan suatu pekerjaan yang secara langsung bertanggng jawab kepada dewan direktur yang dipilih oleh para pemegang saham, yaitu orang yang memiliki perusahaan. Apabila manajer dapat bekerja dengan baik, maka manajer akan dipekerjakan terus, sebaliknya, apabila kinerja manajer tersebut buruk maka dia akan diganti (Rohmad Dwi Jadmiko, 2004: 55).

Etika bisnis sebagai etika terapan sesungguhnya merupakan penerapan dari prinsip-prinsip etika pada umumnya. Konsep responsibility (tanggung jawab) dan fairness (keadilan) merupakan prinsipprinsip etika tersebut yang diimplementasikan dalam wujud CSR. Oleh sebab itu, mengkaji konsep CSR berarti membicarakan konsep tanggung jawab (responsibility) perusahaan dan perwujudan keadilan (fairness) sebagai etika bisnis. Responsibility, pertanggung jawaban perusahaan adalah kepatuhan perusahaan terhadap peraturan yang berlaku, di antaranya termasuk masalah pajak, hubungan industrial, kesehatan dan keselamatan kerja, perlindungan lingkungan hidup, memelihara lingkungan bisnis yang kondusif bersama masyarakat dan sebagainya. Dengan menerapkan prinsip ini, diharapkan akan menyadarkan perusahaan bahwa dalam kegiatan operasionalnya, perusahaan juga mempunyai peran untuk bertanggungjawab selain kepada shareholder juga kepada stakeholders. Fairness, menuntut adanya perlakuan yang adil dalam memenuhi hak shareholder dan stakeholders sesuai dengan peraturan perundangan yang berlaku.

\section{PANDANGAN ISLAM TERHADAP TANGGUNG JAWAB SOSIAL PERUSAHAAN}

Menurut Sayyid Qutb, Islam mempunyai prinsip pertanggungjawaban yang seimbang dalam segala bentuk dan ruang lingkupnya. Antara jiwa dan raga, antara individu dan keluarga, antara individu dan sosial dan, antara suatu masyarakat dengan masyarakat yang lain. Tanggung jawab sosial merujuk pada kewajiban-kewajiban sebuah perusahaan untuk melindungi dan memberi kontribusi kepada masyarakat dimana perusahaan itu berada. Islam mendorong kita untuk memperlakukan setiap muslim secara adil terhadap sesama manusia.

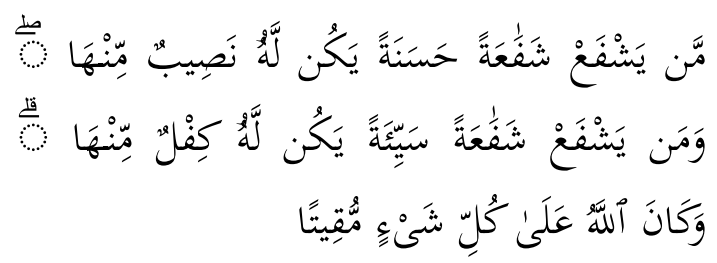

Barang siapa memberikan hasil yang baik, niscaya ia akan memperoleh bagian pahala. Dan barang siapa menimbulkan akibat yang buruk, niscaya ia akan memikul konsekwensinya(Q.S. an-Nisa' [4]: 85) 
Dalam al-Quran Surat an-Nisa' ayat ke 85 ini menegaskan kembali bahwasannya manusia yang menebarkan kebaikan kepada manusia lainya suatu hari ia akan mendapat kebaikan pula dan begitu pula sebaliknya manusia yang menebar benih keburukan kepada manusia lainya maka suatu hari ia akan mendapat keburukan pula. Di ibaratkan perusahaan yang mempunyai citra yang baik dimata masyarakat maka perusahaan akan dipilih oleh masyarakat dalam hal produknya demikian pula perusahaan yang mempunyai citra yang buruk maka produk yang dihasilkan perusahaan akan dihindari masyarakat.

Ada perbedaan mandasar konsep CSR sekular dan Islami. CSR islami berhubungan dengan akhlak dalam melaksanakan business process. Sementara CSR sekular lebih kepada program filantropi. Islam tidak melihat apa yang dihasilkan seseorang tapi nilainya adalah bagaimana proses ia mendapatkan hasil tersebut. Walau dia banyak berderma namun proses mendapatkan dana dengan cara yang haram dan memberi karena riya maka tidak ada nilainya disisi Allah SWT. Walau perusahaan tidak punya program filantropi namun proses bisnis yang dibangun telah membuat karyawan sejahtera, pemegang saham puas, konsumen tidak dirugikan, negara mendapat pajak, lingkungan terpelihara dengan baik, masyarakat mendapatkan manfaat. Itulah islam.Implementasi Corporate Social Responsibility (CSR) dalam Islam secara rinci harus memenuhi beberapa unsur yang menjadikannya ruh sehingga dapat membedakan CSR dalam perspektif Islam dengan CSR secara universal yaitu:

\section{Al-Adl}

Islam telah mengharamkan setiap hubungan bisnis atau usaha yang mengandung kezaliman dan mewajibkan terpenuhinya keadilan yang teraplikasikan dalam hubungan usaha dan kontrak- kontrak serta pejanjian bisnis. Sifat keseimbangan atau keadilan dalam bisnis adalah ketika korporat mampu menempatkan segala sesuatu pada tempatnya. Dalam beraktifitas di dunia bisnis, Islam mengharuskan berbuat adil yang diarahkan kepada hak orang lain, hak lingkungan sosial, hak alam semesta. Jadi, keseimbangan alam dan keseimbangan sosial harus tetap terjaga bersamaan dengan operasional usaha bisnis, dalam al- Quran Surat Huud ayat 85.

2. Al-Ihsan

Islam hanya memerintahkan dan menganjurkan perbuatan baik bagi kemanusiaan, agar amal yang dilakukan manusia dapat memberi nilai tambah dan mengangkat derajat manusia baik individu maupun kelompok. Implementasi Corporate Social Responsibility (CSR) dengan semangat ihsan akan dimiliki ketika individu atau kelompok melakukan kontribusi dengan semangat ibadah dan berbuat karena atas ridho Allah swt. Ihsan adalah melakukan perbuatan baik, tanpa adanya kewajiban 
tertentu untuk melakukan hal tersebut.

3. Manfaat

Konsep ihsan yang telah di jelaskan di atas seharusnya memenuhi unsur manfaat bagi kesejahteran masyarakat (internal maupun eksternal perusahaan). Pada dasarnya, perbankan telah memberikan manfaat terkait operasional yang bergerak dalam bidang jasa yaitu jasa penyimpanan, pembiayaan dan produk atau fasilitas lain yang sangat dibutuhkan masyarakat. Konsep manfaat dalam Corporate Social Responsibility (CSR), lebih dari aktivitas ekonomi.

4. Amanah

Dalam usaha bisnis, konsep amanah merupakan niat dan iktikad yang perlu diperhatikan terkait pengelolaan sumber daya (alam dan manusia) secara makro, maupun dalam mengemudikan suatu perusahaan. Bank yang menerapkan Corporate Social Responsibility (CSR), harus memahami dan menjaga amanah dari masyarakat yang secara otomatis terbebani di pundaknya misalnya menciptakan produk yang berkualitas, serta menghindari perbuatan tidak terpuji dalam setiap aktivitas bisnis.

Dalam perspektif Islam, kebijakan perusahaan dalam mengemban tanggung jawab sosial (CSR) terdapat tiga bentuk implementasi yang dominan yaitu:

1. Tangung jawab sosial (CSR) terhadap para pelaku dalam perusahaan
2. Tanggung jawab sosial (CSR) terhadap lingkungan alam.

3. Tanggung jawab sosial (CSR) terhadap kesejahteraan sosial secara umum.

Islam sangat mendukung Corporate Social Responsibility (CSR) karena tidak dapat dipungkiri bahwa bisnis menciptakan banyak permasalahan sosial, dan perusahaan bertanggung jawab menyelesaikannya. Bisnis membutuhkan berbagai sumber daya alam untuk kelangsungan usaha, sehinga perusahaan bertanggung jawab untuk memeliharanya. Islam secara tidak langsung menganggap bisnis sebagai entitas yang kewajibannya terpisah dari pemiliknya, adanya CSR akan mengembangkan kemauan baik perusahaan tersebut (Muhammad Djakfar, 2007: 12).

\section{PENUTUP}

Menurut Islam, CSR yang dilakukan harus bertujuan untuk menciptakan kebajikan yang dilakukan bukan melalui aktivitasaktivitas yang mengandung unsur riba, melainkan dengan praktik yang diperintahkan Allah berupa zakat, infak, sedekah, dan wakaf. CSR juga harus mengedepankan nilai kedermawanan dan ketulusan hati. Perbuatan ini lebih Allah cintai dari ibadah-ibadah mahdhah. Rasulullah SAW bersabda, "Memenuhi keperluan seorang mukmin lebih Allah cintai dari pada melakukan dua puluh kali haji dan pada setiap hajinya menginfakan ratusan ribu dirham dan dinar". Dalam hadis lain, Rasulullah SAW 
juga bersabda, "Jika seorang muslim berjalan memenuhi keperluan sesama muslim, itu lebih baik baginya daripada melakukan tujuh puluh kali thawaf di Baitullah."

Selain itu, pelaksanaan CSR dalam Islam juga merupakan salah satu upaya mereduksi permasalahan-permasalahan sosial yang terjadi di masyarakat dengan mendorong produktivitas masyarakat dan menjaga keseimbangan distribusi kekayaan di masyarakat. Islam mewajibkan sirkulasi kekayaan terjadi pada semua anggota masyarakat dan mencegah terjadinya sirkulasi kekayaan hanya pada segelintir orang. Allah Berfirman : “...supaya harta itu jangan beredar di antara orang-orang Kaya saja di antara kamu..." (Q.S. Al-Hasyr: 7).

Praktik CSR dalam Islam menekankan pada etika bisnis islami. Operasional perusahaan harus terbebas dari berbagai modus praktik korupsi (fight agains corruption) dan memberi jaminan layanan maksimal sepanjang ranah operasionalnya, termasuk layanan terpercaya bagi setiap produknya (provision and development of safe and reliable products). Hal ini yang secara tegas tercantum dalam Al-Quran. Allah SWT berfirman: ".... Maka sempurnakanlah takaran dan timbangan dan janganlah kamu kurangkan bagi manusia barang-barang takaran dan timbangannya,..." (QS. al-A'raf [7] ayat 85 ).

Selain menekankan pada aktivitas sosial di masyarkat, Islam juga memerintahkan praktik CSR pada lingkungan. Lingkungan dan pelestarianya merupakan salah satu inti ajaran Islam. Prinsip-prinsip mendasar yang membentuk filosofi kebajikan lingkungan yang dilakukan secara holistik oleh Nabi Muhamad SAW adalah keyakinan akan adanya saling ketergantungan di antara makhluk ciptaan Allah. Karena Allah SWT menciptakan alam semesta ini secara terukur, baik kuantitatif maupun kualitatif (lihat QS. Al Qamar: 49) dan dalam kondisi yang seimbang (QS. Al hadid:7). Sifat saling ketergantungan antara makhluk hidup adalah sebuah fitrah dari Allah SWT. Dari prinsip ini maka konsekuensinya adalah jika manusia merusak atau mengabaikan salah satu bagian dari ciptaan Allah SWT, maka alam secara keseluruhan akan mengalami penderitaan yang pada akhirnya juga akan merugikan manusia. Allah SWT berfirman: "telah nampak kerusakan di darat dan di laut disebabkan karena perbuatan tangan manusi, supaya Allah merasakan kepada mereka sebahagian dari (akibat) perbuatan mereka, agar mereka kembali (ke jalan yang benar." (QS. Ar Rum:41)

Dari penjelasan diatas menunjukan bahwa Islam telah mengatur dengan begitu jelas tentang prinsip-prinsip dasar yang terkandung dalam CSR, padahal isu CSR baru dimulai pada abad ke-20. Bahkan dalam berbagai code of conduct yang dibuat oleh beberapa lembaga, Islam telah memberikan penjelasan terlebih dahulu.

\section{DAFTAR KEPUSTAKAAN}

Dwijayanti, Erny, 2013, Pengaruh Pengungkapan Tanggung Jawab 
Sosial terhadap Earning Response Coefficient (ERC), Malang

Widagya dan Triani, 2014, Peranan PSAK No. 33 Pada Perusahaan di Indonesia

Pradipta, D.H. dan Purwaningsih, A. 2012. Pengaruh Luas Pengungkapan Tanggung Jawab Sosial dan Lingkungan Perusahaan Terhadap Earning Response Coefficient (ERC), dengan Ukuran Perusahaan Dan Leverage Sebagai Variabel Kontrol. Simposium Nasional Akuntansi XV. Banjarmasin

Siswoyo, B.B. et. al. 2009. Penyusunan Strategi Kebijakan Efektivitas Pemanfaatan Corporate Social Responsibility (CSR).Kerjasama Bappeda Provinsi Jawa Timur dan Lembaga Penelitian Universitas Negeri Malang

Kalangit, KM. 2009. Konsep Corporate Social Responsibility, Pengaturan dan Pelaksanaannya di Indonesia

K. Bertens, Pengantar Etika Bisnis, Bandung: PT Refika Aditama

Ismail Sholihin, Pengantar Bisnis : Pengenalan Praktis dan Studi Kasus, Jakarta Kencana, 2006

Burhanudin Salam, Etika Sosial (Asas Moral dalam Kehidupan Manusia), Jakarta, Rineka Cipta, 2002

Rafik Isa, Etika Bisnis
Islami,Yogyakarta:Pustaka
Pelajar,2004

Hendrik Budi Untung, Corporate Sosial Responsibility, Bandung: PT Refika Aditama

Yusuf Wibisono, Membedah Konsep dan Aplikasi CSR (Corporate Sosial Responsibility

Nor Hadi, Corporate Sosial Responsibility, Yogyakarta, Graha Ilmu, 2011

Isa Wahyudi dan Bursa Azheri,Corporate Sosial Responsibility:Prinsip, Pengaturan dan Implementasi, Malang: Setara Press, 2011

Rohmad Dwi Jadmiko, Pengantar Bisnis, Malang: UMM Press, 2004

Muhammad Djakfar, Etika Bisnis dalam Perspektif Islam, (Malang: UIN Malang Press, 2007

Undang-Undang No 40 Tahun 2007 mengenai Perseroan Terbatas

Undang-Undang Nomor 19 Tahun 2003 tentang BUMN

Undang-Undang Nomor 20 Tahun 2008 tentang Usaha Mikro, Kecil dan Menengah

Undang-Undang Nomor 25 Tahun 2007 tentang Penanaman Modal

Undang-Undang Nomor 40 Tahun 2007 tentang Perseroan terbatas 